\title{
Specific Metabolites in a Phaeodactylum tricornutum Strain Isolated from Western Norwegian Fjord Water
}

\author{
Siv Kristin Prestegard ${ }^{1,2}$, , Svein Rune Erga ${ }^{3}$, Pia Steinrücken ${ }^{3}$, Svein Are Mjøs ${ }^{4}$, \\ Gjert Knutsen ${ }^{3}$ and Jens Rohloff ${ }^{5}$ \\ Received: 16 September 2015; Accepted: 22 December 2015; Published: 30 December 2015 \\ Academic Editor: Véronique Martin-Jézéquel \\ 1 Bergen Marine Biobank, Department of Biology, University of Bergen, Thormøhlensgate 53A/B, \\ N-5020 Bergen, Norway \\ 2 Applied Biotechnology, Uni Research Environment, Thormøhlensgate 49B, N-5006 Bergen, Norway \\ 3 Department of Biology, University of Bergen, Thormøhlensgate 53AB, N-5020 Bergen, Norway; \\ svein.erga@uib.no (S.R.E.); pia.steinrucken@uib.no (P.S.); gjert.knutsen@uib.no (G.K.) \\ 4 Department of Chemistry, University of Bergen, Allégaten 42, N-5020 Bergen, Norway; svein.mjos@uib.no \\ 5 Department of Biology, Norwegian University of Science and Technology, N-7491 Trondheim, Norway; \\ jens.rohloff@ntnu.no \\ * Correspondence: siv.prestegard@uni.no; Tel.: +47-55-58-26-64
}

\begin{abstract}
We have searched for special characteristics in growth, protein expression, fatty acids and volatile organic compounds (VOCs) in a local Phaeodactylum tricornutum Bohlin strain (Bergen Marine Biobank), by comparing it with a common accession strain (CCAP). Differences in growth and expressed proteins were detected between the BMB strain and the CCAP strain, and the BMB strain reached the highest cell densities under the given growth conditions. Fatty acid (FA) analyses showed highest relative eicosapentaenoic acid (EPA) levels in the exponential phase (25.73\% and $28.31 \%)$, and highest levels of palmitoleic acid (16:1 n-7) in the stationary phase $(46.36 \%$ and $43.66 \%)$ in the BMB and CCAP strain, respectively. The most striking finding of the VOCs analyses was the relatively high levels of ectocarpene, 6-((1E)-butenyl)-1,4-cycloheptadiene, hormosirene, and desmarestene and structurally related compounds, which were exclusively detected in the BMB strain. Many of the VOCs detected in the CCAP and, in particular, in the BMB strain have been reported as antimicrobial agents. We suggest that the array of pheromones and antimicrobial substances could be part of an allelopathic strategy of the BMB strain, dominated by oval cells, thus reflecting the benthic life stage of this morphological form. These findings show the potential for bioactive metabolites in the BMB strain.
\end{abstract}

Keywords: Phaeodactylum tricornutum; two-dimensional gel electrophoresis (2DGE); volatile organic compounds (VOCs); hormosirene; ectocarpene; fatty acids; eicosapentaenoic acid (EPA)

\section{Introduction}

The diatoms represent a large and extraordinary ecologically flexible group of unicellular eukaryotic microalgae. They have acquired genes from an eukaryotic heterotroph and a red algae through secondary endosymbiosis [1] and later through lateral gene transfers from bacteria [2]. The complex genomes of diatoms, together with their ability for sexual reproduction [3], give this genetically highly diverse group many interesting metabolic properties.

Except for the synthesis of primary metabolites like pigments and certain proteins, it is currently impossible to foresee how diatoms will respond metabolically to different sets of growth or stress conditions. The biogenesis of secondary metabolites in diatoms and microalgae in general is unpredictable and needs to be investigated thoroughly. The capability of cells to produce bioactive 
compounds must therefore be examined empirically, and the increasing knowledge of diatom metabolites was excellently reviewed by Stonik, V. and I. Stonik [4]. The sequenced genome of P. tricornutum in 2008 [2] has provided new insight into the molecular foundation of adaption and survival mechanisms to highly changing environments [5,6]. It has been shown that diatoms excrete many of their bioactive compounds, which can have a variety of influences on other species in the plankton community $[7,8]$. Recently, metabolic fingerprinting of metabolites that had been excreted into the surrounding medium from the diatoms Skeletonema marinoi and Thalassiosira pseudonana revealed growth stage dependence [9]. Thus, volatile metabolites originating from exudates from living cells, can also give important information concerning physiological status, and several volatile compounds have been reported to be derivatives from degradation of fatty acids [10,11].

The polymorphic diatom Phaeodactylum tricornutum Bohlin is recognized as a model organism for studies on diatom physiology and genetics. It is also used on an industrial level for aquaculture feed because of its high content of polyunsaturated fatty acids (PUFAs), especially eicosapentaenoic acid (EPA), which is of high value as a food additive to human and animals [12,13].

Phaeodactylum tricornutum can be found in both brackish and marine waters worldwide [14]. Environmental conditions have been reported to induce the transformation between the different morphological cell forms; oval, fusiform, triradiate and cruciform [15-18]. Oval cells of P. tricornutum are considered to represent a benthic life stage since they are most often observed when grown on agar or on the surface of culture containers $[19,20]$.

From a local strain of P. tricornutum, isolated from fjord water in Western Norway [21], more than $95 \%$ of the cells were reported to be oval when grown in liquid bubbled cultures [22]. Water extracts from this strain strongly inhibited blood platelet activation and induced cell death in leukaemia cells. Part of the activity was shown to originate from the high levels of the nucleoside adenosine, while the rest of the activity was shown to originate from other unidentified compounds [21]. The highly interesting metabolic and morphological properties of this isolate motivated us to search for additional special characteristics in growth, protein expression, fatty acids and volatile organic compounds. Fatty acids are also interesting in terms of commercial applications, and they have been reported to be precursors for many volatile metabolites $[10,11]$. Volatile organic compounds (VOC) are part of the metabolome in diatoms and show a high structural variety [10]. Therefore, we wanted to shed light on the VOC fraction in order to reveal characteristic metabolites.

To improve the evaluation of our results, we compared it with a common CCAP strain (CCAP 1052/1A from the Culture Collection of Algae and Protozoa in Oban, UK). Here, we present novel data which make us believe that our local strain has potential for new bioactive metabolites, among which the VOC should be specially emphasized. These compounds comprise both pheromones and antimicrobial substances, which are of great ecological and biomedical importance.

\section{Results}

\subsection{Different Growth and Protein Expression of BMB and CCAP Strains}

Growth curves for the BMB (BMB-E-0007) and CCAP (CCAP 1052/1A) strains are presented in Figure 1A,B. From cell counts, the growth rates corresponding to the sampling day for soluble proteins were determined for both strains. The average growth rate was $0.58 \pm 0.10$ day $^{-1}$ for the BMB strain and $1.07 \pm 0.03 \mathrm{day}^{-1}$ for CCAP from day one to day two. From day three to four, the average growth rate for the BMB strain was $1.01 \pm 0.06$ day $^{-1}$ and $0.98 \pm 0.03$ day $^{-1}$ for the CCAP strain. The CCAP cultures reached their maximal average cell densities of $3.1 \times 10^{7}$ cells $\cdot \mathrm{mL}^{-1}$ at day six, and then the cell numbers started to decrease slowly. The BMB strain cultures reached their maximal average cell densities of $4 \times 10^{7}$ cells. $\mathrm{mL}^{-1}$ at day eleven, and at this time the cultures also obtained the maximal dry weights (Figure 1B). The CCAP strain reached it maximal dry weight at day nine. 


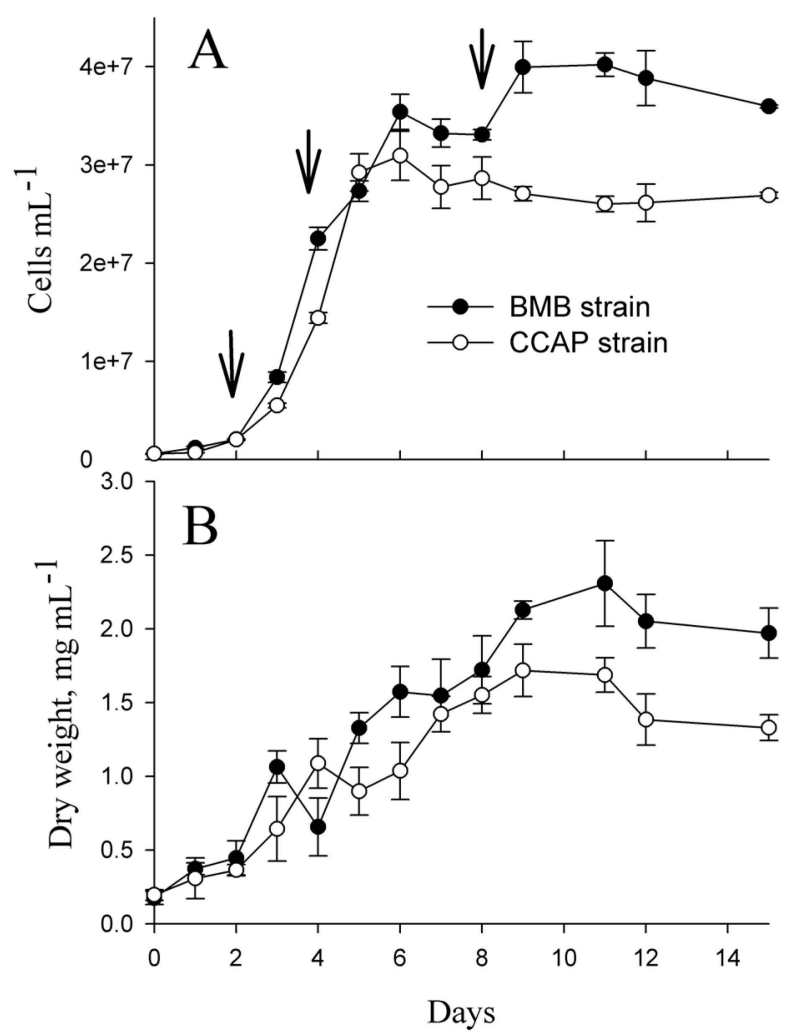

Figure 1. Growth of the BMB and CCAP strains in batch cultures. Cells were grown in artificial seawater with the addition of Walne's medium, $27 \mathrm{PSU}$ at $20^{\circ} \mathrm{C}$ and $249 \mu \mathrm{mol}$ photons $\mathrm{m}^{-2} \cdot \mathrm{s}^{-1}$. (A): Cells. $\mathrm{mL}^{-1}$. Data in Figure 1A are modified from [22]. Arrows shows the time-points for sampling of total soluble proteins. (B): Dry weight $\mathrm{mL}^{-1}$ algae culture. The data in Figure $1 \mathrm{~A}, \mathrm{~B}$ are from the same experiments.

The BMB strain was dominated by oval cells (more than $95 \%$ ), and the CCAP strain was dominated by cells with fusiform morphology (Figure 2A,B). Triradiate cells could occur in the CCAP strain, but it was never observed in the BMB strain.

Total soluble proteins separated by 2DGE from the different growth phases from the BMB and CCAP strains are presented in Figure 3A-F. The protein profiles differed according to growth phases and strain. Total soluble protein and number of resolved spots are presented in Table 1. At day two, more protein spots were resolved from the CCAP strain (372 \pm 41$)$ than from the BMB strain $(197 \pm 11)$, while at day four the number increased for the BMB strain $(289 \pm 18)$ and were reduced for the CCAP strain $(242 \pm 39)$.

Furthermore at day eight, in the stationary growth phase, especially the CCAP strain had strongly reduced resolved protein profiles on the 2DGE gels (Figure 3F). The protein profiles from the BMB strain in the stationary growth phase also revealed reduced number of proteins, but to a lesser extent than in the CCAP profiles (Figure 3C). Differences in the total soluble protein from samples preparations in the CCAP strain $(3.12 \pm 0.30)$ at day 2 compared to the BMB strain $(2.56 \pm 0.45)$ were not significant. Furthermore, the levels decreased by 24 times until day eight in the CCAP strain. The total soluble protein from the BMB strain also decreased towards day eight, but only by 10 times (Table 1). In Figure $3 \mathrm{~A}-\mathrm{C}$ ), an example of a protein that appears to be specific for the BMB strain with an apparent molecular mass $(\mathrm{Mw})$ of $33 \mathrm{kDa}$ and $p \mathrm{I}$ of about 6.2 is marked. The $33 \mathrm{kDa}$ protein was absent from the 2DGE gels separating proteins from the CCAP strain at any growth stage. 

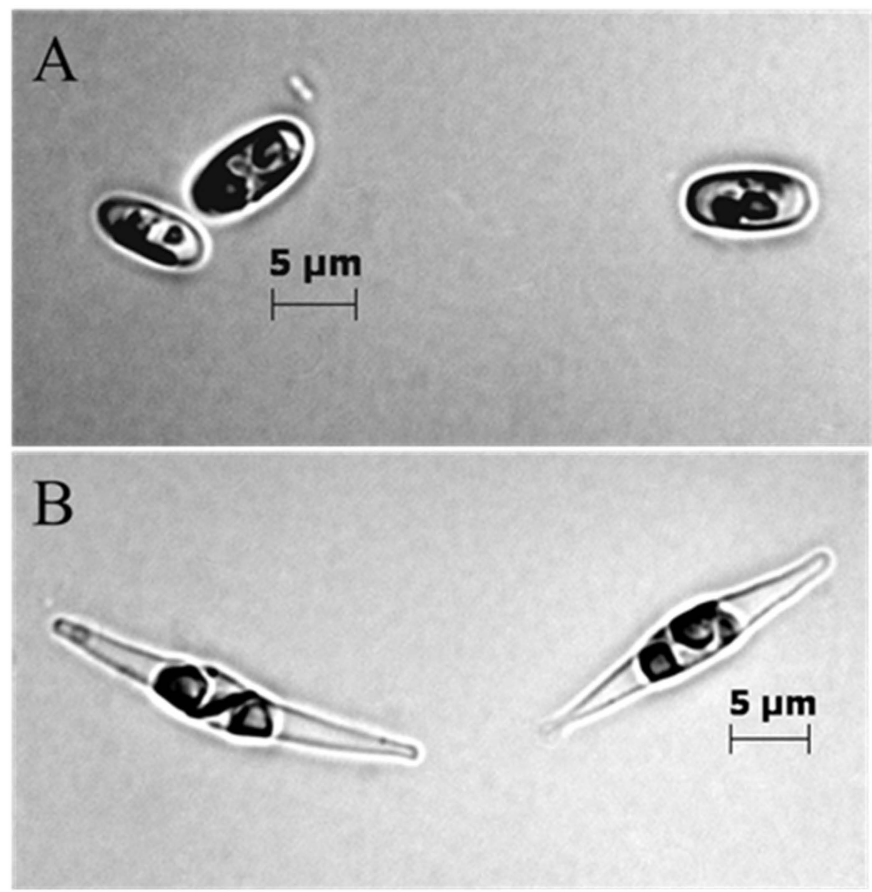

Figure 2. Microscope photos of BMB strain (A) and CCAP (B). A Zeiss Axio Imager Z1 microscope (Carl Zeiss) was used to photograph representative cells from the two strains (100× magnification with immersion oil, Bright Field (A) and Differential interference contrast (B)).
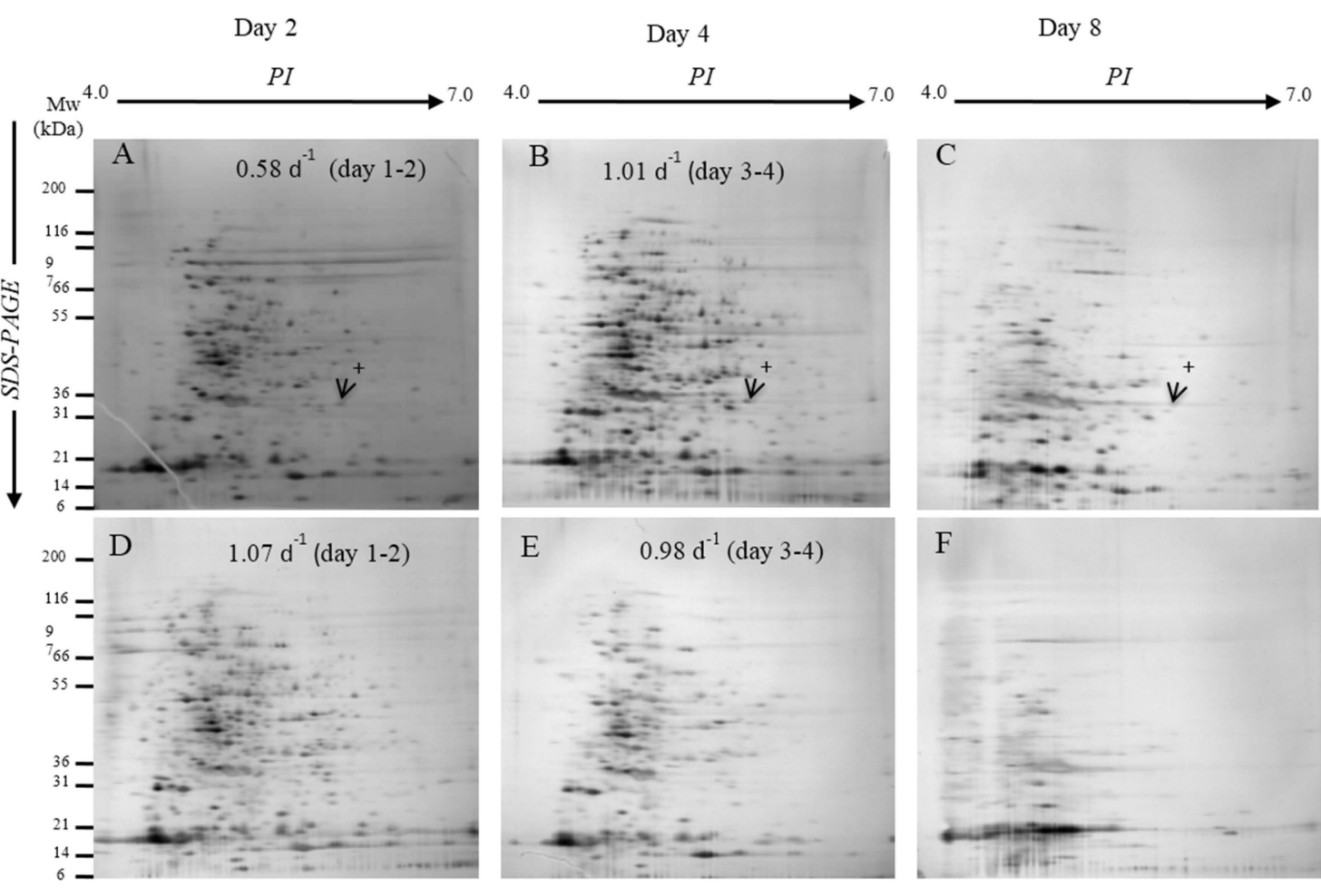

Figure 3. Representatives of protein profiles on 2DGE from BMB strain; (A): day 2; (B): day 4; (C): day 8 and of the CCAP strain; (D): day 2; (E): day 4; (F): day 8. Arrows with cross sign show that protein was present only in $\mathrm{BMB}$ strain. 
Table 1. Total soluble proteins cell ${ }^{-1}$ for samples from BMB and CCAP strain of Phaeodactylum tricornutum for different time points during growth in batch cultures $(n=3)$. Numbers of resolved spots using 2DGE are listed for the different samples $(n=3)$.

\begin{tabular}{lccc}
\hline Strain & Day & Total Soluble Protein, pg/Cell & Resolved Protein Spots by 2DGE \\
\hline BMB & 2 & $2.56 \pm 0.45$ & $197 \pm 11$ \\
& 4 & $0.57 \pm 0.06$ & $289 \pm 18$ \\
& 8 & $0.25 \pm 0.04$ & $198 \pm 19$ \\
\hline CCAP & 2 & $3.12 \pm 0.30$ & $372 \pm 41$ \\
& 4 & $1.10 \pm 0.10$ & $242 \pm 39$ \\
& 8 & $0.13 \pm 0.02$ & $90 \pm 6$ \\
\hline
\end{tabular}

\subsection{Fatty Acid Content and Composition of BMB and CCAP Strains}

Samples taken from exponential and stationary phases of the BMB and CCAP strain were analysed for total fatty acid (FA) content and the relative composition of different FAs. In Figure 4A,B, 19 of the detected FA with relatively levels higher than $1 \%$ are shown. The two strains possess a similar FA composition in both growth phases. In the exponential phase (Figure 4A), eicosapentaenoic acid (EPA) $(20: 5 n-3)$ was the most dominant FA, with $25.73 \% \pm 1.35 \%$ for the BMB strain and $28.31 \% \pm 0.68 \%$ for the CCAP strain. The average cell specific content of EPA is 0.85 and $1.08 \mathrm{pg} \cdot$ cell $^{-1}$ for exponentially growing $\mathrm{BMB}$ and CCAP strains, respectively, and 0.59 and $0.66 \mathrm{pg} \cdot$ cell $^{-1}$, respectively, for stationary cells (see Figure 4A-C). In the stationary phase (Figure 4B), palmitoleic acid (16:1 n-7) became the predominant FA with $46.36 \% \pm 0.16 \%$ of the total FA in the BMB strain and $43.66 \% \pm 1.05 \%$ in the CCAP strain. Also, the levels of the saturated palmitic acid (16:0) had increased to $29.3 \%$ and $32.1 \%$ in the BMS and CCAP strain, respectively. EPA levels were reduced to $6.17 \% \pm 0.06 \%$ for the BMB strain and $8.26 \% \pm 0.21 \%$ for the CCAP strain in the stationary phase.
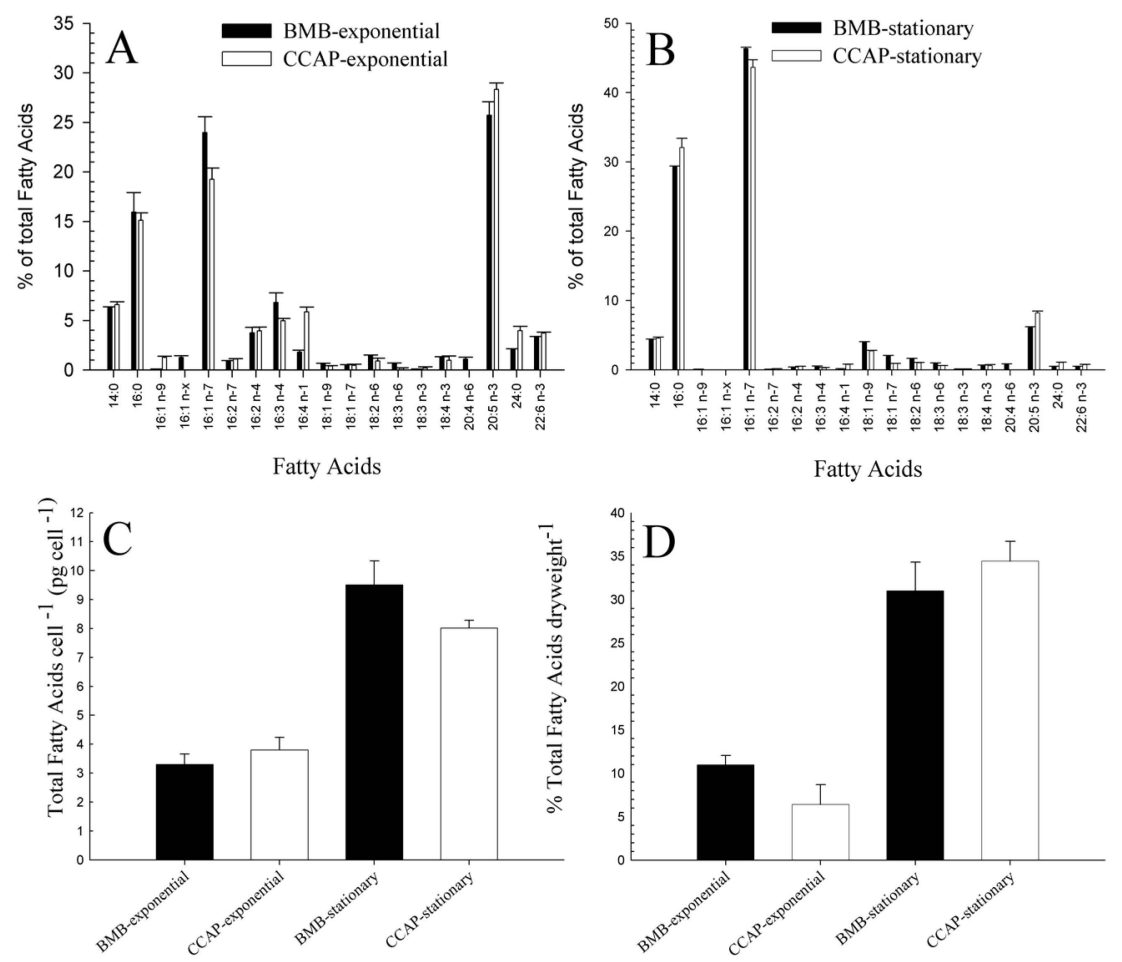

Figure 4. Fatty acid (FA) profiles given as \% of total FA of BMB and CCAP strain in exponential phase (A) and in stationary phase (B). Total FA per cell in BMB and CCAP strain in exponential and stationary phase (C) and \% of total FA per dry weight (D). 
In the exponential growth phase, a higher relative fraction of the fatty acids consisted of long chain fatty acids and polyunsaturated FAs, whereas in the stationary phase, a higher fraction of the shorter fatty acids (C16 and 16:1 n-7) was present. The total amount of fatty acids per cell more than doubled from exponential phase to stationary phase for both strains (Figure $4 \mathrm{C}$ ). In the stationary phase, the BMB strain had a slightly higher total FA per cell $(9.51 \mathrm{pg} \pm 0.82)$ than the CCAP strain (8.02 pg \pm 0.26 ). In the exponential phase, $10.98 \% \pm 1.1 \%$ of the dry biomass in the BMB strain was FA, and in the stationary phase it had increased to $31.01 \% \pm 3.31 \%$. In the CCAP strain, $6.4 \% \pm 2.27 \%$ of the dry algae biomass was fatty acids in the exponential phase and $34.44 \% \pm 2.26 \%$ in the stationary phase (Figure $4 \mathrm{D}$ ).

\subsection{Differences in Volatile Organic Compounds (VOCs) from BMB and CCAP Strains}

VOCs from early stationary cultures of BMB and CCAP strain of P. tricornutum were collected and analysed by headspace SPME-GC-MS. A broad range of 61 structurally different VOCs were tentatively identified, comprising aliphatics ( 6 alkanes, 4 aldehydes, 1 ketone, 4 acids, 2 esters), sulphides (3), terpenes (3 monoterpenes, 1 sesquiterpene, 1 triterpene), aromatics (3), furans (1), quinones (1), carotenoid-derived volatiles (6), and alicyclic olefins (18). Furthermore, 7 non-identified peaks were structurally assigned as aliphatic hydrocarbons (4) and aromatics (3) (Table 2). In general, a distinct higher number of VOCs could be isolated from the BMB strain (55) compared to the CCAP strain of P. tricornutum (36). The most striking observation in the BMB strain was the abundance of the algal pheromones ectocarpene, 6-((1E)-butenyl)-1,4-cycloheptadiene, hormosirene and desmarestene. Further 14 non-identified pheromonal volatiles were structurally annotated based on their characteristic and similar MS fragmentation patterns and the occurrence of the molecular ions of identified pheromones with $(\mathbf{M}+) \mathrm{m} / z=148$ (compounds No. 22-24) and (M+) $m / z=146$ (compound No. 30) (Table 2).

The content of 6-((1E)-butenyl)-1,4-cycloheptadiene comprised $58.5 \%$ of the detected VOCs in the BMB strain. The gas chromatographic separation of pheromones of the BMB strain is depicted in Figure 5. These alicyclic olefins were totally absent in the volatile profiles of the CCAP strain.

Table 2. Volatile organic compounds (VOC) from BMB strain and CCAP strain of Phaeodactylum tricornutum, analysed by headspace SPME coupled with GC-MS. Structurally-identified compounds are marked in italics and characterized by their most prominent mass ion fragments (relative intensity in $\%$ in parentheses).

\begin{tabular}{|c|c|c|c|c|c|}
\hline No. & $\mathbf{R I}^{\#}$ & COMPOUND & $\begin{array}{c}\text { BMB-E-0007; \% of } \\
\text { Total }\end{array}$ & $\begin{array}{l}\text { CCAP 1052/1A; \% } \\
\text { of Total }\end{array}$ & MS Fragments \\
\hline 1 & 516 & dimethyl sulfide & 2.91 & 7.82 & \\
\hline 2 & 746 & dimethyl disulfide & 0.42 & - & \\
\hline 3 & 792 & 2-hexanone & - & 2.31 & \\
\hline 4 & 867 & $p$-xylene & - & 1,40 & \\
\hline 5 & 941 & $\alpha$-pinene & 0.06 & 0.84 & \\
\hline 6 & 966 & dimethyl trisulfide & 0.25 & - & \\
\hline 7 & 983 & 6-methyl-5-hepten-2-one & 0.10 & 2.52 & \\
\hline 8 & 1017 & 2,2,6-trimethyl-cyclohexanone & 0.13 & 1.12 & \\
\hline 9 & 1027 & 1,8-cineole & 0.27 & 5.42 & \\
\hline 10 & 1029 & limonene & 0.88 & 6.47 & \\
\hline 11 & 1037 & acetophenone & - & 3.81 & \\
\hline 12 & 1060 & 3-methyl decane & - & 0.47 & \\
\hline 13 & 1070 & aliphatic hydrocarbon & 0.11 & 5.68 & $\begin{array}{c}m / z=43,57,71,85,97 \\
111,125\end{array}$ \\
\hline 14 & 1077 & aliphatic hydrocarbon & - & 1.62 & $\begin{array}{c}m / z=43,57,71,85,98 \\
111,123\end{array}$ \\
\hline 15 & 1080 & 3-acetyl-2,5-dimethyl furan & 0.17 & - & \\
\hline
\end{tabular}


Table 2. Cont

\begin{tabular}{|c|c|c|c|c|c|}
\hline No. & RI $\#$ & COMPOUND & $\begin{array}{l}\text { 3MB-E-0007; \% of } \\
\text { Total }\end{array}$ & $\begin{array}{l}\text { CCAP 1052/1A; \% } \\
\text { of Total }\end{array}$ & MS Fragments \\
\hline 16 & 1099 & nonanal & 0.19 & 1.52 & \\
\hline 17 & 1100 & undecane & 0.39 & 1.31 & \\
\hline 18 & 1126 & 4-oxoisophorone & 0.17 & 6.27 & \\
\hline 19 & 1133 & putative pheromonal VOC & 1.12 & - & $\begin{array}{l}m / z=146(10), 117(100) \\
91(70), 104(45), 115(50)\end{array}$ \\
\hline 20 & 1134 & aliphatic hydrocarbon & - & 1.99 & $m / z=43,57,71,85,113$ \\
\hline 21 & 1141 & aromatic compound & 0.07 & 5.78 & \\
\hline 22 & 1163 & ectocarpene & 5.41 & - & \\
\hline 23 & 1166 & 6-((1E)-butenyl)-1,4-cycloheptadiene & 58.52 & - & \\
\hline 24 & 1169 & hormosirene & 0.21 & - & \\
\hline 25 & 1176 & putative pheromonal VOC & 2.24 & - & $\begin{array}{c}m / z=148(10), 91(100) \\
79(50), 119(40), 105(35)\end{array}$ \\
\hline 26 & 1179 & aromatic compound & 0.25 & 1.72 & $\begin{array}{c}m / z=122(100), 107(95) \\
77(78), 91(36)\end{array}$ \\
\hline 27 & 1185 & putative pheromonal VOC & 0.63 & - & $\begin{array}{c}m / z=148(5), 91(100) \\
79(90), 105(45)\end{array}$ \\
\hline 28 & 1187 & putative pheromonal VOC & 0.92 & - & $\begin{array}{l}m / z=146(45), 117(100) \\
91(90), 131(90), 115(75)\end{array}$ \\
\hline 29 & 1190 & octanoic acid & 0.07 & 0.95 & \\
\hline 30 & 1192 & desmarestene & 1.01 & - & \\
\hline 31 & 1203 & decanal & 0.18 & 1.52 & \\
\hline 32 & 1209 & $\beta$-cyclocitral & 0.06 & 1.57 & \\
\hline 33 & 1213 & putative pheromonal VOC & 2.30 & - & $\begin{array}{c}m / z=148(50), 91(100) \\
105(60), 119(45)\end{array}$ \\
\hline 34 & 1237 & putative pheromonal VOC & 0.34 & - & $\begin{array}{c}m / z=146(40), 91(100) \\
117(90), 131(40)\end{array}$ \\
\hline 35 & 1246 & putative pheromonal VOC & 0.12 & - & $\begin{array}{c}m / z=148(45), 91(100) \\
79(50), 105(40), 119(40)\end{array}$ \\
\hline 36 & 1249 & aromatic compound & 0.14 & - & $\begin{array}{c}m / z=148(25), 122(100) \\
107(85), 91(50), 77(45)\end{array}$ \\
\hline 37 & 1273 & putative pheromonal VOC & 0.40 & - & $\begin{array}{c}m / z=148(50), 91(100) \\
105(50), 119(45), 77(40)\end{array}$ \\
\hline 38 & 1284 & nonanoic acid & 0.15 & 3.78 & \\
\hline 39 & 1291 & putative pheromonal VOC & 0.04 & - & $\begin{array}{c}m / z=162(17), 147(100) \\
119(60), 91(25)\end{array}$ \\
\hline 40 & 1300 & tridecane & 0.10 & 4.99 & \\
\hline 41 & 1310 & putative pheromonal VOC & 9.43 & - & $\begin{array}{c}m / z=162(3), 147(2) \\
91(100), 79(25), 105(22)\end{array}$ \\
\hline 42 & 1313 & putative pheromonal VOC & 0.60 & - & $\begin{array}{c}m / z=148(7), 79(100) \\
91(70), 67(65), 135(25)\end{array}$ \\
\hline 43 & 1322 & putative pheromonal VOC & 0.62 & - & $\begin{array}{l}m / z=146(15), 79(10) \\
91(80), 67(60), 53(40)\end{array}$ \\
\hline 44 & 1327 & aliphatic hydrocarbon & 0.98 & - & $\mathrm{m} / \mathrm{z}=43,57,71,85$ \\
\hline 45 & 1335 & cyclo- $\beta$-ionone & 0.23 & 1.69 & \\
\hline 46 & 1346 & putative pheromonal VOC & 2.24 & - & $\begin{array}{l}m / z=166(20), 67(100) \\
81(60), 95(55), 109(50)\end{array}$ \\
\hline 47 & 1382 & decanoic acid & 0.04 & 1.37 & \\
\hline 48 & 1388 & putative pheromonal VOC & 0.31 & - & $\begin{array}{c}m / z=164(30), 91(95) \\
79(70), 105(55)\end{array}$ \\
\hline 49 & 1410 & dodecanal & 0.16 & 1.84 & \\
\hline 50 & 1449 & geranyl acetone & 0.24 & 4.47 & \\
\hline 51 & 1460 & 2,6-di-tert-butyl- $p$-benzoquinone & 0.18 & 1.84 & \\
\hline 52 & 1504 & 2,4-di-tert-butyl phenol & 0.07 & 0.98 & \\
\hline 53 & 1558 & butyl decanoate & 0.88 & 3.05 & \\
\hline
\end{tabular}


Table 2. Cont.

\begin{tabular}{lcccc}
\hline No. & RI ${ }^{\#}$ & COMPOUND & $\begin{array}{c}\text { BMB-E-0007; of } \\
\text { Total }\end{array}$ & $\begin{array}{c}\text { CCAP 1052/1A; } \% \\
\text { of Total }\end{array}$ \\
\hline 54 & 1592 & tetradecanal & 0.10 & MS Fragments \\
\hline 55 & 1595 & dodecanoic acid & 0.03 & 1.38 \\
\hline 56 & 1815 & $(E, E)$-farnesyl acetate & 0.16 & 1.43 \\
\hline 57 & 2000 & eicosane & 0.30 & - \\
\hline 58 & 2178 & ethyl hexadecanoate & 0.44 & 2.67 \\
\hline 59 & 2200 & docosane & 0.05 & 6.14 \\
\hline 60 & 2832 & squalene & 2.24 & 1.13 \\
\hline 61 & 3000 & triacontane & 0.34 & 100 \\
\hline \multicolumn{7}{c}{ sum $\%$} & 100 & $1.28 \mathrm{E}+06$ \\
\hline
\end{tabular}

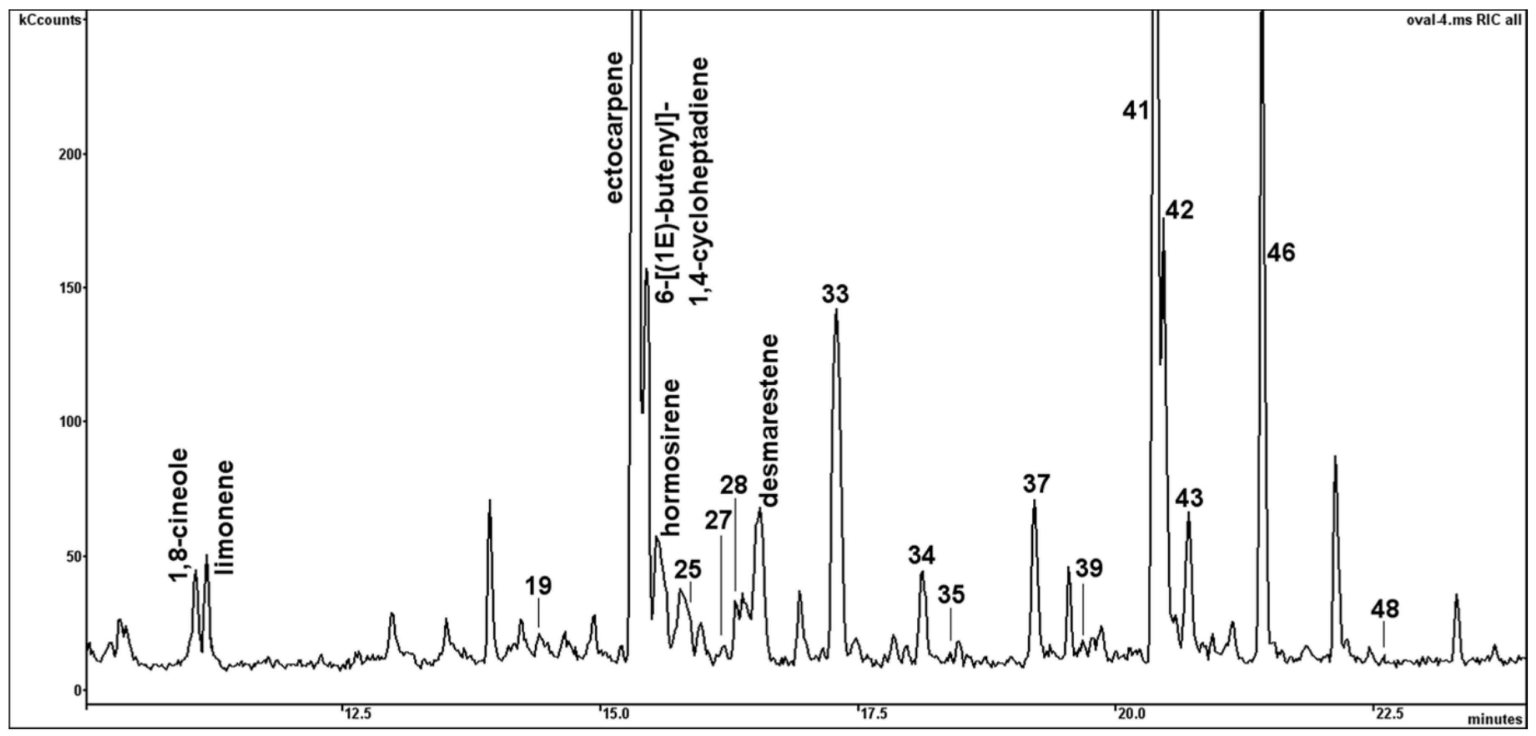

Figure 5. Example of GC-MS chromatogram showing the separation pattern of pheromonal VOCs and monoterpenes, detected in the BMB strain. Numbers indicate volatile compounds listed in Table 2.

\section{Discussion}

The interesting metabolic properties and the generally great phenotypic variation shown in P. tricornutum isolates motivated us to search for additional characteristics in growth, protein expression, FA profiles and VOCs in a BMB strain isolated from Western Norwegian fjord water. All experiments and analyses were run in parallel with a common CCAP strain for comparison. The BMB strain was shown to be dominated by oval cells (Figure 2A), and the CCAP strain (Figure 2B) by fusiform cells. The oval cell form of $P$. tricornutum has in several studies been emphasized to be a benthic life form, which is supported by the fact that fusiform cells grown on agar surfaces will transform into slightly motile oval cells surrounded by extracellular polymeric substances. It was also reported that oval cells transferred from agar into liquid medium would gradually revert to fusiform cells [19]. It is therefore an interesting feature of the BMB strain that it can be maintained oval in liquid bubbled cultures. Epigenetic changes have recently been shown to have an important role in phenotypic variation [23]. It is not unlikely that the polymorphism seen in P. tricornutum could be related to epigenetic phenomena. Epigenetic regulation has been shown for P. tricornutum, and extensive gene methylation correlated strongly with differential expression under specific conditions [24]. Proteomics 
can be one approach to reveal epigenetic effects [25], and here we have shown differences in soluble proteins separated by 2DGE between the BMB and CCAP strain in different growth phases. These differences indicate that the two P. tricornutum strains are under different transcriptional or epigenetic regulation, but a more in depth study is required to be able to reveal more about regulation of expressed proteins.

Growth parameters like cell numbers and dry weight and also expressed proteins are important parameters to describe physiological status of microalgae cultures. When the CCAP cultures had the maximal growth rates at day two, the highest number of expressed proteins on the 2DGE gels was observed (Figure 3D and Table 1). The successive increase in growth rate for the BMB strain from day one to day two and from day three to four co-occurred with an increased number of proteins on the 2DGE gels at day four (Figure 3B and Table 1). This is in accordance with the increased need for proteins in cell division when growth rates increase. A decreased number of separated proteins at day four is observed for the CCAP cells (Figure 3E), and this can indicate that a turnover of the proteins had occurred, a process that allows the cells to re-utilize amino acids and change protein content. These findings are supported by a recent study of $P$. tricornutum and its responses to nitrogen deprivation, where the authors showed that following nitrogen deprivation, a reduction in biosynthesis and an increase in recycling of $\mathrm{N}$-containing compounds like amino acids, proteins and nucleic acid occurred at the transcript level [26]. It has also been shown that as the growth rate decreased, the overall rate of protein turnover decreased in P. tricornutum [27]. The highly reduced numbers of expressed proteins found in the early stationary phase (day 8 ) in our study have also been observed in a stationary culture of the dinoflagellate Prorocentrum triestinum [28]. Nitrogen limitation has been shown to decrease the cell protein content and abundance of proteins like ribulose bisphosphate carboxylase/oxygenase [29]. A characteristic protein observed for the BMB strain was one with molecular weight of about $33 \mathrm{kDa}$ and $p \mathrm{I}$ of about 6.2 (Figure $3 \mathrm{~A}-\mathrm{C}$ ). This finding did not correspond to the presence of a $21 \mathrm{kDa}$ protein found in the fusiform cells detected from comparison of protein bands from clonal cultures of oval and fusiform cells in one-dimensional SDS-PAGE gels [30], hence the $33 \mathrm{kDa}$ protein appears to be specific to the BMB strain.

Fatty acids are metabolites of high commercial interest and with many interesting cellular functions. In microalgae, they are building blocks in cellular lipids like the polar membrane lipids and the neutral lipids [31]. Some fatty acids have also been shown to possess antibacterial properties [32]. In our studies, the total amount of fatty acids per cell and per dry weight increased more than two times from exponential to stationary phase in both strains. At the same time, both strains showed a similar shift in their relative FA composition. The higher relative content of long chain polyunsaturated FA (especially EPA) in exponential phase changed to a higher fraction of monounsaturated and saturated fatty acids, especially palmitoleic acid (16:1 n-7) in the stationary phase. Both the increase in total FA and the shift towards saturation and monounsaturation in the stationary phase have been documented for P. tricornutum by others $[33,34]$ and can be related to the accumulation of neutral storage lipids (triacylglycerols, TAG) as a response to nitrogen starvation in the stationary phase. They serve as storage compounds for carbon and energy and predominantly consist more of saturated and monounsaturated fatty acids, while polyunsaturated fatty acids (PUFA) are typically present in membrane lipids [31]. Interestingly, EPA has also been reported to have high antibacterial activity $[35,36]$. In another study, it was found that extracts from fusiform cells had higher antibacterial activity and higher content of the fatty acids EPA, hexadecatrienoic acid and palmitoleic acid than extracts from oval cells [32]. It is interesting to note that here in our study the BMB strain (dominated by oval cells) had higher relative amounts (Figure 4B) and cell specific amounts of palmitoleic acid (average $4.41 \mathrm{pg} \cdot$ cell $^{-1}$ ) than the CCAP strain (average $3.50 \mathrm{pg} \cdot$ cell $^{-1}$, dominated by fusiform cells) in the stationary phase.

Even if most of the VOCs described are highly volatile and hydrophobic, they are still slightly soluble in water and can be bioactive, i.e., molecules can be sensed by other individuals of the same species or even other species in the context of defense.Volatile metabolites originating from exudates 
from living cells can give important information concerning physiological status, and several volatile compounds have been reported to be derivatives from degradation of fatty acids. More volatile metabolites could be detected from the oval cells (55) than from the fusiform cells (36). Interestingly the higher number of separated protein spots in the stationary phase of the BMB strain co-occurred with an increased number of detected VOCs. The bouquet of cultures of the BMB P. tricornutum strain has a distinct pleasant smell, probably from the high levels of 6-((1E)-butenyl)-1,4-cycloheptadiene or possibly from ectocarpene. The most striking findings of the VOCs analyses in our study were the relative high levels of ectocarpene, 6-((1E)-butenyl)-1,4-cycloheptadiene, hormosirene, and desmarestene and related structurally-assigned compounds, which were exclusively detected in the BMB cultures. The occurrence of ectocarpene in P. tricornutum and other diatom species have been reported earlier [37,38], and the production of hormosirene in the freshwater diatom Gomphonema parvulum has also been reported [7]. Ectocarpene, hormosirene and the intermediate 6-((1E)-butenyl)-1,4-cycloheptadiene have been identified from brown algae, where their biochemical function are described to be coupled to male gametophyte release and sexual attraction [39-42]. However, hormosirene has also been found in the brown algae of the genus Dictyopteris spp, showing no connection to sexual reproduction [43]. The occurrence of the pheromone dictyopterene $C$ in P. tricornutum [37] could not be confirmed by our study. It is interesting to note that the pheromone desmarestene has not been detected in diatoms so far. The presence of C11 unsaturated olefins (pheromones) in the volatile fraction from cultures of the BMB strain is likely to originate from oxylipin chemistry. The biosynthesis of $\mathrm{C} 11$ unsaturated olefins in diatoms and brown algae is based upon eicosanoid precursors, and the cleavage of these fatty acids results in C11 hydrocarbons and oxoacids $[7,10]$. We have shown that the BMB strain contained high levels of potential FA precursors for bioactive oxylipins.

It is tempting to suggest that the presence of the pheromone "cocktail" released from the oval cells in the BMB strain reflects its benthic life stage where the oval cells are assumed to dominate, even if they were grown in liquid cultures in our study. To our current knowledge, the fusiform and oval cells, typically representing the CCAP and BMB strain, respectively, are not associated with sexual differentiation since comparison of the DNA content in three different cell types of P. tricornutum revealed no significant differences [44]. These pheromones and aldehydes may act as allelochemicals for the organisms in order to protect themselves against competitors or grazers, or it may be part of a quorum sensing strategy. Quorum sensing involves the production and detection of certain signalling molecules (also called auto-inducers and pheromones) by organisms [45]. The possible roles of these pheromones should be examined further.

Diatoms belong to the large group of Heterokontophyta, a major line of eukaryotic algae. Although there are phylogenetic differences between unicellular diatoms from the class Bacillariophyceae and the brown algae from the class Phaeophyceae, they share common biochemical features such as chlorophylls, carotenoids, fatty acids and hydrocarbons [37], and can thus, probably share pathways leading to the biosynthesis of pheromonal-active VOCs. This is also true with regard to the identification of terpenoid structures in our study, whose biosynthesis and abundance have high significance in terrestrial plants. Three monoterpenes were detected in our P. tricornutum strains, which are in accordance with the detection of terpenes such as $\alpha$-pinene and limonene in diatoms and other phytoplankton species, recently being reported [46]. In addition to this, the oxygenated monoterpene 1,8-cineole and the triterpene squalene have been identified from a red algae species [47]. Another common feature is the release of S-containing volatiles (sulphides), which are known to be produced by both phytoplankton [48] and other marine organisms [49]. In contrast, halogenated VOCs [50] could not be detected by HS-SPME in our study probably due to high volatility and low abundance of these structures.

Many of the detected VOCs in our study (Table 2) are chemicals reported to exert antibiotic activity, such as 1,8-cineole [51], $\alpha$-pinene and limonene [52,53] and octanoic acid (caprylic acid) [54]. Our findings indicate that $P$. tricornutum cells produce an arsenal of antimicrobial compounds 
probably to protect themselves against bacteria. Several studies have reported the transformation of polyunsaturated fatty acid (PUFA) into unsaturated aldehydes upon mechanical damage of diatom cells. These unsaturated aldehydes have been shown to have a negative effect on the copepod reproductive process, and they induce apoptosis in human carcinoma cells [55]. They are therefore thought to be a part of the defence system in diatoms thus contributing to an increase in the overall success of many diatom species [56]. Such unsaturated aldehydes were not detected in the VOCs from the strains in our study, but this is not unexpected since it depends upon mechanical breakage of cells, which typically occurs during grazing. However, water extracts from four isolates of P. tricornutum, including the BMB strain, strongly inhibited blood platelet activation and induced cell death in leukaemia cells. The origin of activity was not chemically identified, but it was shown not to originate from adenosine [21]. The apoptotic effects could come from oxylipins released when preparing the extracts, although further isolation and characterisation of the active compounds in water extracts must be conducted to confirm this suggestion. It is interesting to note that all of the four P. tricornutum isolates from Western Norwegian fjords were dominated by oval cells, and it is therefore tempting to suggest that cells representing a benthic life stage of P. tricornutum contain a variety of bioactive metabolites with the purpose of increasing the survival of cells living on surfaces in the intertidal zone.

We have presented data on growth and protein expression, which confirm that the BMB strain had the potential to fully exploit the growth conditions in our experiments and thereby obtain higher cell densities and dry-weights than the non-local strain, which is a prerequisite for biomass production of microalgae for aquaculture or even for biofuel [57]. The BMB strain also showed high levels of EPA, a known precursor of bioactive metabolites, often found in the volatile fraction of the culture. The results from the volatile profiling in our study suggest that further investigations of the diatom P. tricornutum should focus on asexual life stages both in pelagic and benthic environments, in order to reveal novel VOCs patterns and potential allelopathic functions in inter-species communication. Furthermore as it is realized that the life span for antibiotics is limited, there is a continuous search for new candidates [58]. Therefore, further investigations on the benthic diatoms as a source for new antibiotics, anti-cancer and other bioactivities should be intensified, adding new focus to other parts of the metabolome like the volatile organic compounds. The volatile fraction of large scale cultures of microalgae can be an important by-product that can be exploited and add value to the cultivation of microalgae. Local isolates of P. tricornutum like the BMB strain should be investigated for their biomedical potential, such as products of oxylipin chemistry, like 2,4-decadienal, which have been shown to induce apoptosis in cancer cells, and in copepods and sea urchin embryos [59]. Interestingly, many anti-cancer agents used by stalwart drugs share common properties with oxylipins derived from diatoms, including teratogenic and anti-mitotic activities [60].

In view of the wide distribution of diatoms, their role as the world's most important primary producer and their metabolic capabilities, we strongly believe that increased knowledge of their biology in combination with improved analytical chemical methods will reveal many new and important metabolites in the years to come.

\section{Experimental Section}

\subsection{Cultivation of BMB and CCAP Strains for Growth and Proteins Analyses}

The BMB strain of P. tricornutum was isolated and maintained in stock culture as strain ND58 as described [21]. It is now an accession (BMB-E-0007) in Bergen Marine Biobank (BMB) at Department of Biology, University of Bergen, Norway and Uni Research AS. The second strain of P. tricornutum was strain CCAP 1052/1A from the Culture Collection of Algae and Protozoa in Oban, UK. Both isolates have been maintained under identical conditions since 1997 [22]. BMB and CCAP strain were grown as batch cultures at $20^{\circ} \mathrm{C}$ in sterile Walne's medium [61] prepared with artificial seawater (ASW) [62] with salinity of $27 \mathrm{PSU}$ in $300 \mathrm{~mL}$ glass cylinders with $3.5 \mathrm{~cm}$ in inner diameter. Humidified air mixed with $\mathrm{CO}_{2}\left(1 \% \mathrm{CO}_{2}\right.$ final concentration) was filtered through bacterial filters $(0.2 \mu \mathrm{m})$ and bubbled through 
the cultures. Cultures were provided with continuous white light of $249 \mu \mathrm{mol}$ photons $\mathrm{m}^{-2} \cdot \mathrm{s}^{-1}$ at the front of the cultures. Scalar irradiance was measured at the fronts of the cultures with a spherical sensor (Biospherical Instruments Inc. QSL-100, San Diego, CA, USA).

Six parallel cultures, each consisting of $280 \mathrm{~mL}$, were grown as batch cultures. For every sampling for protein analyses, one of these cultures was harvested by centrifugation at $2000 \mathrm{rpm}$ for $5 \mathrm{~min}$ in $50 \mathrm{~mL}$ aliquots at day 2, 4 and 8. The cells were carefully washed twice in sterile ASW before pelleted, frozen in liquid nitrogen and stored at $-80{ }^{\circ} \mathrm{C}$ until analysed. The cultures were not axenic, but bacterial numbers were kept at a minimum using sterile technique, sterilized equipment and media. The presence of bacteria was observed daily in a microscope (100× magnification with immersion oil).

A Zeiss Axio Imager Z1 microscope (Carl Zeiss) was used to photograph representative cells from the two strains $(100 \times$ magnification with immersion oil).

\subsection{Growth Measurements}

Cell counts, growth determinations and dry weight were performed as described in [22].

\subsection{Preparation of Protein Samples}

Each protein sample was prepared from three parallel extractions from three cell pellets, each from a culture volume of $50 \mathrm{~mL}$. Each pellet was dissolved in $0.3 \mathrm{~mL}$ precipitation solution, consisting of acetone with 10\% TCA (Trichloroacetic acid) and $20 \mathrm{mM} \mathrm{DTT}$ (Dithiotreitol, GE Healthcare Bio-Sciences, Pittsburgh, PA, USA). The cells were disrupted in the precipitation solution using glass beads $(0.45 \mathrm{~mm}$, BioSpec Products, Bartesville, OK, USA), and they were mixed with a vortex blender seven times for $1 \mathrm{~min}$, allowing the samples to cool on ice between the pulses. The protein extracts were removed and the beads were washed twice with $0.5 \mathrm{~mL}$ of the precipitation solution, and these washes were pooled with the first extract and left to precipitate $\mathrm{o} / \mathrm{n}$ at $-20^{\circ} \mathrm{C}$. The precipitated proteins were centrifuged at $4{ }^{\circ} \mathrm{C}$ at $17,500 \mathrm{~g}$ for $30 \mathrm{~min}$ and the protein pellets were re solubilised in $1.5 \mathrm{~mL}$ acetone (with $20 \mathrm{mM}$ DTT) to remove TCA and left to precipitate for $2 \mathrm{~h}$ at $-20^{\circ} \mathrm{C}$. This was repeated at least twice or until the pellet appeared white with no remnants of pigments. The protein pellets were dissolved in $0.4 \mathrm{~mL}$ rehydration buffer containing $2 \mathrm{M}$ thiourea, $7 \mathrm{M}$ urea, $4 \%$ CHAPS, $0.5 \%$ Triton X-100, $20 \mathrm{mM}$ DTT and $0.5 \%$ Zoom ${ }^{\circledR}$ Carrier Ampholytes $\mathrm{pH} 3-10$ or pH 4-7 from Invitrogen (Waltham, MA, USA) at room temperature overnight. Unsolved proteins were removed by centrifugation at $17,500 \mathrm{~g}$ at $4{ }^{\circ} \mathrm{C}$ for $30 \mathrm{~min}$. Quantification of protein in each parallel extraction was performed using the Bio Rad RC DC protein assay (Bio-Rad, Hercules, CA, USA). The calibration curves were prepared using BSA dissolved in the same rehydration buffer as sample $(0.2-1.5 \mathrm{mg} / \mathrm{mL})$ and the absorption of the solution was recorded at $750 \mathrm{~nm}$ using a Shimadzu spectrophotometer (UV-2401PC). After the protein concentrations had been measured, the three parallel protein extracts were pooled, representing the sample from that time-point and strain.

\subsection{Two Dimensional Gel Electrophoresis (2DGE)}

ZOOM $^{\circledR}$ IPGRunner ${ }^{\mathrm{TM}}$ System from Invitrogen ${ }^{\mathrm{TM}}$ (USA) was used for the first dimension isoelectric focusing (IEF) and second dimension SDS-PAGE. The $7 \mathrm{~cm}$ immobilised $\mathrm{pH}$ gradient gels (IPG) Zoom ${ }^{\circledR}$ Strips from Invitrogen ${ }^{\mathrm{TM}} \mathrm{pH} 4-7$ were used. Protein samples were applied to the strips as described by the manufacturer, and the best resolution in silver stained gels was obtained by loading $10 \mu \mathrm{g}$ protein to each gel $(n=3)$.

IEF running conditions were modified according to the manufacturer's recommendations and running conditions were as follows: $0.5 \mathrm{~h}$ at $100 \mathrm{~V}, 1 \mathrm{~h}$ at $200 \mathrm{~V}$ and $5 \mathrm{~h}$ at $500 \mathrm{~V}$ using the PowerEase ${ }^{\circledR}$ 500 from Invitrogen. After IEF the strips were frozen as recommended [63] overnight at $-20{ }^{\circ} \mathrm{C}$ before equilibrated in DTT and IAA (Iodoacetamide, Sigma Aldrich, St. Louis, MO, USA) before running the second dimension as described in the manual. The second dimension was performed using NuPage ${ }^{\circledR}$ Novex $4 \%-12 \%$ Bis-Tris Zoom ${ }^{\circledR}$ Gels from Invitrogen and comigrated with a broad range molecular weight marker (2.5 to $200 \mathrm{kDa}$ ). SDS-PAGE was run for 50-60 min at $200 \mathrm{~V}$. 


\subsection{Visualization, Imaging and Analysis of Gels}

The gels were stained with a MS compatible SilverQuest ${ }^{\mathrm{TM}}$ Silver Staining Kit from Invitrogen (cat. no. LC6070). Gels were scanned using Bio imaging system from SynGene, and images were saved in TIFF format before analysed with Delta 2D version 3.5 (DECODON). Images were filtered to remove the background noise, and gel pictures of three parallel gels from the same sample preparation were fused to create a master gel representative for that particular sample. Another master gel was prepared from three parallel gel pictures from the other sample preparation, and these two master gels were again compared to monitor the reproducibility of the sample preparation procedure and the 2DGE run. The master gels were compared, day 2 with day 4 , day 4 with day 8 for BMB strain and the same for the CCAP strain. Next, day 2 for oval cells were compared with day 2 for fusiform and so on and analysed for differences in the number of expressed protein spots (Figure 3).

\subsection{Cultivation of Strains for Determination of Total Fatty Acids and Profiling}

Two parallel batch cultures of the BMB (BMB-E-0007) and the CCAP strain were grown in sterile Walne's medium as previous, but prepared with aged seawater and distilled water (80:20, v:v, 29 PSU) in $300 \mathrm{~mL}$ glass cylinders as described in Section 4.1, using a light intensity of $150 \mu \mathrm{mol}$ photons $\mathrm{m}^{-2} \cdot \mathrm{s}^{-1}$. Cultures were sampled daily for cell counting, $\mathrm{pH}$, and once during mid exponential (day 3 ) and late stationary phase (day 10) for fatty acid and dry weight analysis. Counts of algae cells were performed by flowcytometry (FCM, FACSCalibur, Becton and Dickinson, Franklin Lakes, NJ, USA) for $60 \mathrm{~s}$ at high flow velocity with cultures diluted to give 20-100 events/s. The exact flow rate $R$ $\left(\mu \mathrm{L} \cdot \min ^{-1}\right)$ was calculated by applying culture medium to the FCM and using the following equation $\left(\mathrm{W}_{\mathrm{i}}-\mathrm{W}_{\mathrm{f}}\right) / t \cdot \rho$, with $\mathrm{W}_{\mathrm{i}}=$ initial weight $(\mathrm{mg}), \mathrm{W}_{\mathrm{f}}=$ final weight $(\mathrm{mg}), t=$ time $(\mathrm{min}), \rho=$ density $\left(1 \mathrm{~g} \cdot \mathrm{cm}^{-3}\right)$. Dry weight concentration was determined using $0.5 \mathrm{M}$ ammonium formate as washing buffer as described [64]. For fatty acids determination, $10 \mathrm{~mL}$ of microalgal culture were sampled in $10 \mathrm{~mL}$ glass tubes (PYREX), centrifuged for $6 \mathrm{~min}$ at $4000 \mathrm{~g}$ and relived from the supernatant. Pellets were stored in nitrogen atmosphere at $-20^{\circ} \mathrm{C}$ until analysed.

\subsection{Fatty Acid Extraction}

Samples were derivatized to fatty acid methyl esters (FAME) by direct esterification according to [65]. Briefly, the sample pellet was dried in the $10 \mathrm{~mL}$ tubes by evaporating water under nitrogen atmosphere. Internal standard, 23:0 FAME dissolved in isooctane, was added $(150 \mu \mathrm{L}, 0.240 \mathrm{mg} / \mathrm{mL}$ or $100 \mu \mathrm{L}, 4.90 \mathrm{mg} / \mathrm{mL}$ for samples in exponential or stationary phase, respectively). After evaporating the solvent, $0.5 \mathrm{~mL}$ methylation reagent $(2 \mathrm{M} \mathrm{HCl}$ in methanol) was immediately added to each tube. The tubes were flushed with nitrogen, sealed and incubated in oven at $90^{\circ} \mathrm{C}$ for $2 \mathrm{~h}$. After cooling to room temperature, half of the methanol was evaporated and $0.5 \mathrm{~mL}$ water was added. The samples were thereafter extracted twice by $1 \mathrm{~mL}$ isooctane. Before analysis by gas chromatography (GC), the combined extracts were further diluted by isooctane (1:2 or 1:20 for exponential or stationary phase samples, respectively).

\subsection{FAME Analysis by Gas Chromatography and Mass Spectrometry (GC-MS)}

The FAMEs were analysed on a 7890 gas chromatograph (Agilent, Santa Clara, CA, USA) equipped with autosampler, split-splitless injector, flame ionization detector (FID) and a $60 \mathrm{~m}$ BPX70 capillary column (SGE, Ringwood, Australia) with internal diameter $0.25 \mathrm{~mm}$ and film thickness of $0.25 \mu \mathrm{m}$. Samples of $1 \mu \mathrm{L}$ were injected splitless at $60^{\circ} \mathrm{C}$ where the temperature was held for $3 \mathrm{~min}$ before it was raised by $40{ }^{\circ} \mathrm{C} / \mathrm{min}$ to $150^{\circ} \mathrm{C}$ followed by $1.5^{\circ} \mathrm{C} / \mathrm{min}$ to $230^{\circ} \mathrm{C}$. Helium was used as carrier gas in constant flow mode with an estimated average velocity at injection of $30 \mathrm{~cm} / \mathrm{s}$. Injector and detector temperatures were $250{ }^{\circ} \mathrm{C}$ and $300^{\circ} \mathrm{C}$, respectively.

Identification of FAMEs was performed by analyzing selected samples on an Agilent 7890/5977 GC-MS system, using the same capillary column as in GC-FID. Conditions and methodology were 
as described in [66]. Data handling of GC-FID and GC-MS data were performed in Chrombox C and Chrombox Q, respectively (www.chrombox.org).

\subsection{Sampling of Volatiles by Headspace Solid-Phase Microextraction (SPME)}

Preliminary tests with non-polar and semi-polar SPME fibre types showed that the $75 \mu \mathrm{m}$ Carboxen $^{\mathrm{TM}} /$ PDMS fibre (Supelco Inc., Bellefonte, PA, USA) showed highest sensitivity towards the broad range of structurally different volatile organic compounds (VOCs) from cultures of $P$. tricornutum. The fibre, mounted on a manual SPME holder (Supelco Inc.), was exposed to the GC inlet in a blank run for $2 \mathrm{~min}$ for thermal desorption at $220^{\circ} \mathrm{C}$ prior to headspace sampling. $2.5 \mathrm{~mL}$ of each Phaeodactylum strain in early stationary phase $(n=3)$ was sealed in a $15 \mathrm{~mL}$ screw-capped vial with a phenolic cap and a PTFE/silicone septum (Supelco Inc.). The SPME fibre was exposed to the sample for $7 \mathrm{~h}$ by manually penetrating the septum $(0.25 \mathrm{~cm}$ depth). The SPME device was immediately inserted into the GC injector and the fibre thermally desorbed for $3 \mathrm{~min}$ at $220^{\circ} \mathrm{C}$.

\subsection{Volatile Analysis by Gas Chromatography and Mass Spectrometry (GC-MS)}

A Varian Star 3400 CX gas chromatograph (Varian Inc., Walnut Creek, CA, USA) coupled with a Varian Saturn 3 mass spectrometer were used for all analyses. An Agilent J \& W DB-5 fused silica capillary column was applied for the chromatographic separation of VOCs: $30 \mathrm{~m} \times 0.25 \mathrm{~mm}$ i.d., $0.25 \mu \mathrm{m}$ film thickness. Helium was used as carrier gas $(15 \mathrm{psi})$ at $50 \mathrm{~mL} / \mathrm{min}$ through the injector and $30 \mathrm{~cm} / \mathrm{s}$ through the column. The injector temperature was set at $220^{\circ} \mathrm{C}$ carried out in splitless mode for $2 \mathrm{~min}$. The GC temperature was a held at $40^{\circ} \mathrm{C}$ for $2 \mathrm{~min}$, ramped from $40{ }^{\circ} \mathrm{C}$ to $220^{\circ} \mathrm{C}$ at a rate of $4.5^{\circ} \mathrm{C} / \mathrm{min}$, and finally held at $220^{\circ} \mathrm{C}$ for $3 \mathrm{~min}$. The MS detector was set at $220^{\circ} \mathrm{C}$ and a mass range of $m / z 25-300$ was recorded. All mass spectra were acquired with electron impact ionization. VOCs were tentatively identified based on mass spectrum database search (NIST/EPA/NIH mass spectral library v.2.0, 2005), in combination with retention indices and comparison of mass spectra found in literature. Based on compound-characteristic MS fragmentation patterns, several VOCs were structurally-annotated (Table 2) relating to the groups of aliphatic hydrocarbons, aromatic compounds or pheromonal VOC.

Acknowledgments: This research was supported by the Norwegian Research Council (NFR), grant No. $139710 / 140$.

Author Contributions: Prestegard, S.K., Knutsen, G., Erga, S.R., Rohloff, J. conceived and designed the experiments; Prestegard, S.K., Steinrücken, P., Mjøs, S.A. and Rohloff, J. performed the experiments; Prestegard, S.K., Erga, S.R., Steinrücken, P., Mjøs, S.A. and Rohloff, J. analyzed the data; Mjøs, S.A., Erga, S.R., Knutsen, G. and Rohloff, J. contributed reagents/materials/analysis tools; Writing of the paper; Prestegard, S.K., Rohloff, J., Steinrücken, P., Erga, S.R., Knutsen, G., and Mjøs, S.A.

Conflicts of Interest: The authors declare no conflict of interest.

\section{References}

1. Medlin, L.K.; Kooistra, W.C.H.F.; Schmid, A.M.M. A review of the evolution of diatoms: A total approach using molecules, morphology and geology. In The Origin and Early Evolution of the Diatoms; Witkowski, A., Sieminska, J., Eds.; Polish Academy of Sciences: Cracow, Poland, 2000; pp. 13-35.

2. Bowler, C.; Allen, A.E.; Badger, J.H.; Grimwood, J.; Jabbari, K.; Kuo, A.; Maheswari, U.; Martens, C.; Maumus, F.; Otillar, R.P.; et al. The Phaeodactylum genome reveals the evolutionary history of diatom genomes. Nature 2008, 456, 239-244. [CrossRef] [PubMed]

3. Mann, D.G. Patterns of sexual reproduction in diatoms. Hydrobiologia 1993, 269, 11-20. [CrossRef]

4. Stonik, V.; Stonik, I. Low molecular weight metabolites from diatoms: Structures, biological roles and biosynthesis. Mar. Drugs 2015, 13, 3672-3709. [CrossRef] [PubMed]

5. Kroth, P.G.; Chiovatti, A.; Gruber, A.; Martin-Jezequel, V.; Moch, T.; Parker, M.S.; Stanley, M.S.; Kaplan, A.; Caron, L.; Weber, T.; et al. A model for carbohydrate metabolism in the diatom Phaeodactylum tricornutum deduced from comparative whole genome analysis. PLoS ONE 2008, 3, e1426. [CrossRef] [PubMed] 
6. Allen, A.E.; LaRoche, J.; Maheswari, U.; Lommer, M.; Schauer, N.; Lopez, P.J.; Finazzi, G.; Fernie, A.R.; Bowler, C. Whole-cell response of the pennate diatom Phaeodactylum tricornutum to iron starvation. Proc. Natl. Acad. Sci. USA 2008, 105, 10438-10443. [CrossRef] [PubMed]

7. Pohnert, G.; Boland, W. Biosynthesis of the algal pheromone hormosirene by the freshwater diatom Gomphonema parvulum (Bacillariophyceae). Tetrahedron 1996, 52, 10073-10082. [CrossRef]

8. Pohnert, G.; Lumineau, O.; Cueff, A.; Adolph, S.; Cordevant, C.; Lange, M.; Poulet, S. Are volatile unsaturated aldehydes from diatoms the main line of chemical defence against copepods? Mar. Ecol. Prog. Ser. 2002, 245, 33-45. [CrossRef]

9. Barofsky, A.; Vidoudez, C.; Pohnert, G. Metabolic profiling reveals growth stage variability in diatom exudates. Limnol. Oceanogr. Meth. 2009, 7, 382-390. [CrossRef]

10. Pohnert, G.; Boland, W. The oxylipin chemistry of attraction and defense in brown algae and diatoms. Nat. Prod. Rep. 2002, 19, 108-122. [PubMed]

11. Schobert, B.; Elstner, E.F. Production of hexanal and ethane by Phaeodactylum triconutum and its correlation to fatty-acid oxidation and bleaching of photosynthetic pigments. Plant Physiol. 1980, 66, 215-219. [CrossRef] [PubMed]

12. Yongmanitchai, W.; Ward, O.P. Growth of and omega-3-fatty-acid production by Phaeodactylum tricornutum under different culture conditions. Appl. Environ. Microbiol. 1991, 57, 419-425. [PubMed]

13. Atalah, E.; Cruz, C.M.H.; Izquierdo, M.S.; Rosenlund, G.; Caballero, M.J.; Valencia, A.; Robaina, L. Two microalgae Crypthecodinium cohnii and Phaeodactylum tricornutum as alternative source of essential fatty acids in starter feeds for seabream (Sparus aurata). Aquaculture 2007, 270, 178-185. [CrossRef]

14. De Martino, A.; Meichenin, A.; Shi, J.; Pan, K.H.; Bowler, C. Genetic and phenotypic characterization of Phaeodactylum tricornutum (Bacillariophyceae) accessions. J. Phycol. 2007, 43, 992-1009. [CrossRef]

15. Johansen, J.R. Morphological variability and cell-wall composition of Phaeodactylum tricornutum (Bacillariophyceae). Great Bas. Nat. 1991, 51, 310-315.

16. Lewin, J.C.; Lewin, R.A.; Philpott, D.E. Observations on Phaeodactylum tricornutum. J. Gen. Microbiol. 1958, 18, 418-426. [CrossRef] [PubMed]

17. Borowitzka, M.A.; Volcani, B.E. Polymorphic diatom Phaeodactylum tricornutum ultrastructure of its morphotypes. J. Phycol. 1978, 14, 10-21. [CrossRef]

18. He, L.Y.; Han, X.T.; Yu, Z.M. A rare Phaeodactylum tricornutum cruciform morphotype: Culture conditions, transformation and unique fatty acid characteristics. PLoS ONE 2014, 9. [CrossRef]

19. Lewin, J.C. The taxonomic position of Phaeodactylum tricornutum. J. Gen. Microbiol. 1958, 18, 427-432. [CrossRef] [PubMed]

20. Round, F.E.; Crawford, R.M.; Mann, D.G. Diatoms: Biology and Morphology of the Genera; Cambridge University Press: New York, USA, 1990; p. 560.

21. Prestegard, S.; Oftedal, L.; Coyne, R.T.; Nygaard, G.; Skjærven, K.H.; Knutsen, G.; Døskeland, S.O.; Herfindal, L. Marine benthic diatoms contain compounds able to induce leukemia cell death and modulate blood platelet activity. Mar. Drugs 2009, 7, 605-623. [CrossRef] [PubMed]

22. Prestegard, S.K.; Knutsen, G.; Herfindal, L. Adenosine content and growth in the diatom Phaeodactylum tricornutum (Bacillariophyceae): Effect of salinity, light, temperature and nitrate. Diatom Res. 2014, 29, 361-369. [CrossRef]

23. Hildebrand, M.; Dahlin, K. Nitrate transporter genes from the diatom Cylindrotheca fusiformis (Bacillariophyceae): mRNA levels controlled by nitrogen source and by the cell cycle. J. Phycol. 2000, 36, 702-713. [CrossRef]

24. Veluchamy, A.; Lin, X.; Maumus, F.; Rivarola, M.; Bhavsar, J.; Creasy, T.; O’Brien, K.; Sengamalay, N.A.; Tallon, L.J.; Smith, A.D.; et al. Insights into the role of DNA methylation in diatoms by genome-wide profiling in Phaeodactylum tricornutum. Nat. Commun. 2013, 4. [CrossRef] [PubMed]

25. Bull, A.T.; Ward, A.C.; Goodfellow, M. Search and discovery strategies for biotechnology: The paradigm shift. Microbiol. Mol. Biol. Rev. 2000, 64, 573-606. [CrossRef] [PubMed]

26. Alipanah, L.; Rohloff, J.; Winge, P.; Bones, A.M.; Brembu, T. Whole-cell repsonse to nitrogen deprivation in the diatom Phaeodactylum tricornutum. J. Exp. Bot. 2015. [CrossRef] [PubMed]

27. Quigg, A.; Beardall, J. Protein turnover in relation to maintenance metabolism at low photon flux in two marine microalgae. Plant Cell Environ. 2003, 26, 693-703. [CrossRef] 
28. Chan, L.L.; Hodgkiss, I.J.; Wan, J.M.F.; Lum, J.H.K.; Mak, A.S.C.; Sit, W.H.; Lo, S.C.L. Proteomic study of a model causative agent of harmful algal blooms, Prorocentrum triestinum II: The use of differentially expressed protein profiles under different growth phases and growth conditions for bloom prediction. Proteomics 2004, 4, 3214-3226. [CrossRef] [PubMed]

29. Geider, R.J.; Laroche, J.; Greene, R.M.; Olaizola, M. Response of the photosynthetic apparatus of Phaeodactylum tricornutum (Bacillariophyceae) to nitrate, phosphate, or iron starvation. J. Phycol. 1993, 29, 755-766. [CrossRef]

30. Gutenbrunner, S.A.; Thalhamer, J.; Schmid, A.M.M. Proteinaceous and immunochemical distinctions between the oval and fusiform morphotypes of Phaeodactylum tricornutum (Bacillariophyceae). J. Phycol. 1994, 30, 129-136. [CrossRef]

31. Olofsson, M.; Lamela, T.; Nilsson, E.; Berge, J.P.; del Pino, V.; Uronen, P.; Legrand, C. Seasonal variation of lipids and fatty acids of the microalgae Nannochloropsis oculata grown in outdoor large-scale photobioreactors. Energies 2012, 5, 1577-1592. [CrossRef]

32. Desbois, A.P.; Walton, M.; Smith, V.J. Differential antibacterial activities of fusiform and oval morphotypes of Phaeodactylum tricornutum (Bacillariophyceae). J. Mar. Biol. Assoc. UK 2010, 90, 769-774. [CrossRef]

33. Breuer, G.; Lamers, P.P.; Martens, D.E.; Draaisma, R.B.; Wijffels, R.H. The impact of nitrogen starvation on the dynamics of triacylglycerol accumulation in nine microalgae strains. Bioresour. Technol. 2012, 124, 217-226. [CrossRef] [PubMed]

34. Liang, Y.; Beardall, J.; Heraud, P. Changes in growth, chlorophyll fluorescence and fatty acid composition with culture age in batch cultures of Phaeodactylum tricornutum and Chaetoceros muelleri (Bacillariophyceae). Bot. Mar. 2006, 49, 165-173. [CrossRef]

35. Desbois, A.P.; Lebl, T.; Yan, L.M.; Smith, V.J. Isolation and structural characterisation of two antibacterial free fatty acids from the marine diatom Phaeodactylum tricornutum. Appl. Microbiol. Biotechnol. 2008, 81, 755-764. [CrossRef] [PubMed]

36. Desbois, A.P.; Mearns-Spragg, A.; Smith, V.J. A fatty acid from the diatom Phaeodactylum tricornutum is antibacterial against diverse bacteria including multi-resistant Staphylococcus aureus (MRSA). Mar. Biotechnol. 2009, 11, 45-52. [CrossRef] [PubMed]

37. Wendel, T.; Jüttner, F. Lipoxygenase-mediated formation of hydrocarbons and unsaturated aldehydes in freshwater diatoms. Phytochemistry 1996, 41, 1445-1449. [CrossRef]

38. Derenbach, J.B.; Pesando, D. Investigations into a small fraction of volatile hydrocarbons III. Two diatom cultures produce ectocarpene, a pheromone of brown algae. Mar. Chem. 1986, 19, 337-341. [CrossRef]

39. Stratmann, K.; Boland, W.; Müller, D.G. Biosynthesis of pheromones in female gametes of marine brown algae (Phaeophyceae). Tetrahedron 1993, 49, 3755-3766. [CrossRef]

40. Kodama, K.; Matsui, K.; Hatanaka, A.; Kajiwara, T. Sex-attractants secreted from female gametes of Japanese brown algae of the genus Scytosiphon. Phytochemistry 1993, 32, 817-819. [CrossRef]

41. Müller, D.G.; Kawai, H.; Stache, B.; Fölster, E.; Boland, W. Sexual pheromones and gamete chemotaxis in Analipus japonicus (Phaeophyceae). Experientia 1990, 46, 534-536. [CrossRef]

42. Maier, I.; Müller, D.G. Sexual pheromones in algae. Biol. Bull. 1986, 170, 145-175. [CrossRef]

43. Schnitzler, I.; Pohnert, G.; Hay, M.; Boland, W. Chemical defense of brown algae (Dictyopteris spp.) against the herbivorous amphipod Ampithoe longimana. Oecologia 2001, 126, 515-521. [CrossRef]

44. Marshall Darley, W. Deoxyribonucleic acid content of the three cell types of Phaeodactylum tricornutum Bohlin. J. Phycol. 1968, 4, 219-220. [CrossRef]

45. Bassler, B.L. How bacteria talk to each other: Regulation of gene expression by quorum sensing. Curr. Opin. Microbiol. 1999, 2, 582-587. [CrossRef]

46. Yassaa, N.; Peeken, I.; Zollner, E.; Bluhm, K.; Arnold, S.; Spracklen, D.; Williams, J. Evidence for marine production of monoterpenes. Environ. Chem. 2008, 5, 391-401. [CrossRef]

47. Kamenarska, Z.; Ivanova, A.; Stancheva, R.; Stoyneva, M.; Stefanov, K.; Dimitrova-Konaklieva, S.; Popov, S. Volatile compounds from some black sea red algae and their chemotaxonomic application. Bot. Mar. 2006, 49, 47-56. [CrossRef]

48. Vogt, M.; Turner, S.; Yassaa, N.; Steinke, M.; Williams, J.; Liss, P. Laboratory inter-comparison of dissolved dimethyl sulphide (DMS) measurements using purge-and-trap and solid-phase microextraction techniques during a mesocosm experiment. Mar. Chem. 2008, 108, 32-39. [CrossRef] 
49. Liss, P.S.; Hatton, A.D.; Malin, G.; Nightingale, P.D.; Turner, S.M. Marine sulphur emissions. Philos. Trans. R. Soc. Lond. B Biol. Sci. 1997, 352, 159-168. [CrossRef]

50. Abrahamsson, K.; Choo, K.S.; Pedersen, M.; Johansson, G.; Snoeijs, P. Effects of temperature on the production of hydrogen peroxide and volatile halocarbons by brackish-water algae. Phytochemistry 2003, 64, 725-734. [CrossRef]

51. Carson, C.F.; Mee, B.J.; Riley, T.V. Mechanism of action of Melaleuca alternifolia (tea tree) oil on Staphylococcus aureus determined by time-kill, lysis, leakage, and salt tolerance assays and electron microscopy. Antimicrob. Agents Chemother. 2002, 46, 1914-1920. [CrossRef] [PubMed]

52. Andrews, R.E.; Parks, L.W.; Spence, K.D. Some effects of Douglas fir terpenes on certain microorganisms. Appl. Envir. Microbiol. 1980, 40, 301-304.

53. Uribe, S.; Ramirez, J.; Pena, A. Effects of beta-pinene on yeast membrane functions. J. Bacteriol. 1985, 161, 1195-1200. [PubMed]

54. Hismiogullari, S.E.; Elyurek, E.; Hismiogullari, A.A.; Sahin, F.; Basalan, M.; Yenice, S. Effects of caproic and caprylic acids on microbial growth and cytotoxicity. J. Anim. Vet. Adv. 2008, 7, 731-735.

55. Miralto, A.; Barone, G.; Romano, G.; Poulet, S.A.; Ianora, A.; Russo, G.L.; Buttino, I.; Mazzarella, G.; Laabir, M.; Cabrini, M.; et al. The insidious effect of diatoms on copepod reproduction. Nature 1999, 402, 173-176. [CrossRef]

56. Pohnert, G. Phospholipase $\mathrm{A}_{2}$ activity triggers the wound-activated chemical defense in the diatom Thalassiosira rotula. Plant Physiol. 2002, 129, 103-111. [CrossRef] [PubMed]

57. Duong, V.T.; Li, Y.; Nowak, E.; Schenk, P.M. Microalgae isolation and selection for prospective biodiesel production. Energies 2012, 5, 1835-1849. [CrossRef]

58. Cowan, M.M. Plant products as antimicrobial agents. Clin. Microbiol. Rev. 1999, 12, 564-582. [PubMed]

59. Romano, G.; Russo, G.L.; Buttino, I.; Ianora, A.; Miralto, A. A marine diatom-derived aldehyde induces apoptosis in copepod and sea urchin embryos. J. Exp. Biol. 2003, 206, 3487-3494. [CrossRef] [PubMed]

60. Blagosklonny, M.V. Teratogens as anti-cancer drugs. Cell Cycle 2005, 4, 1518-1521. [CrossRef] [PubMed]

61. Walne, P.R. Studies on the Food Value of Nineteen Genera of Algae to Juvenile Bivalves of the Genera Ostrea, Crassostrea, Mercenaria and Mytilus; H.M. Stationery Office: London, UK, 1970; Volume 26, pp. 1-62.

62. Kester, D.R.; Duedall, I.W.; Connors, D.N.; Pytkowicz, R.M. Preparation of artificial seawater. Limnol. Oceanogr. 1967, 12, 176-179. [CrossRef]

63. Wang, S.B.; Hu, Q.; Sommerfeld, M.; Chen, F. An optimized protocol for isolation of soluble proteins from microalgae for two-dimensional gel electrophoresis analysis. J. Appl. Phycol. 2003, 15, 485-496. [CrossRef]

64. Zhu, C.J.; Lee, Y.K. Determination of biomass dry weight of marine microalgae. J. Appl. Phycol. 1997, 9, 189-194. [CrossRef]

65. Meier, S.; Mjos, S.A.; Joensen, H.; Grahl-Nielsen, O. Validation of a one-step extraction/methylation method for determination of fatty acids and cholesterol in marine tissues. J. Chromatogr. A 2006, 1104, 291-298. [CrossRef] [PubMed]

66. Wasta, Z.; Mjos, S.A. A database of chromatographic properties and mass spectra of fatty acid methyl esters from omega-3 products. J. Chromatogr. A 2013, 1299, 94-102. [CrossRef] [PubMed]

(C) 2015 by the authors; licensee MDPI, Basel, Switzerland. This article is an open access article distributed under the terms and conditions of the Creative Commons by Attribution (CC-BY) license (http:/ / creativecommons.org/licenses/by/4.0/). 